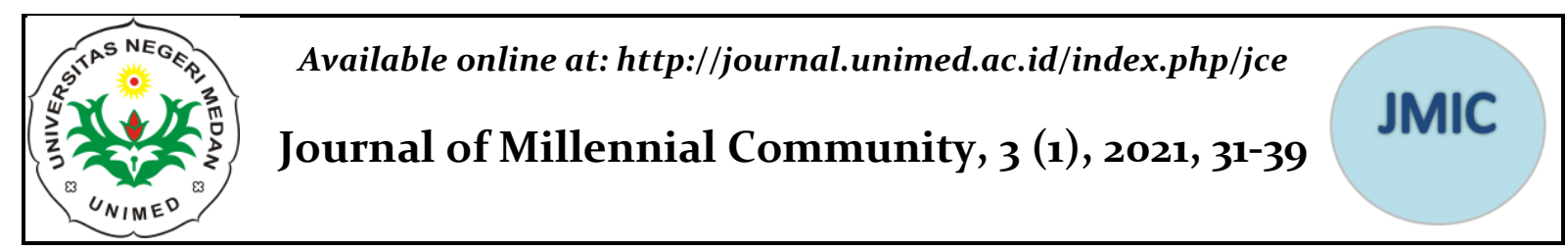

\title{
Penggunaan Google Form Sebagai Alat Evaluasi Pembelajaran Ujian Pendidikan Kesetaraan Paket C Secara Daring Di SPNF SKB Wilayah 1 Kota Padang
}

\author{
Lilis Swarni Nainggolan', Arif Nur Rohman ${ }^{2}$ \\ Satuan Pendidikan Non Formal Sanggar Kegiatan Belajar (SPNF SKB) Wilayah 1 \\ Kota Padang, Sumatera Barat, Indonesia \\ Email: nainggolanlilis57@gmail.com
}

\begin{abstract}
Abstrak
Penelitian ini bertujuan untuk melihat pemanfaatan google form dalam pelaksanaan evaluasi pembelajaran ujian pendidikan kesetaraan pada peserta didik paket $C$ (setara SMA) tahun ajaran 2020/ 2021 di SPNF SKB Wilayah 1 Kota Padang. Metode yang digunakan dalam penelitian ini adalah kualitatif dengan pendekatan deskriptif. Dengan Teknik pengumpulan data berupa observasi dan studi dokumentasi dari subyek penelitian yaitu tutor/ pendidik yang mengampu mata pelajaran di kelas XII (dua belas) yang diujikan dalam UPK program paket $C$ tahun 2021 di SPNF SKB Wilayah I Kota Padang. Hasil dari penelitian ini menunjukan bahwa pelaksanaan evaluasi program kesetaraan (ujian Pendidikan kesetaraan) di paket $C$ yang diikuti oleh peserta didik kelas XII diketahui bahwa peserta didik yang melaksanakan UPK lebih banyak menggunakan metode daring (google form).
\end{abstract}

Kata Kunci: Evaluasi Pembelajaran, Google Form, Program Paket $C$

\section{Using Google Forms as a Learning Evaluation Tool for the Online Exam of Senior High School Equality Education Program (Paket C)}

\begin{abstract}
This study aims to see the utilization of google form in the implementation of the evaluation of equality education exam learning in students senior high school student equality education program (Paket C) 2020 / 2021 in SKB SPNF Region 1 Padang City. The method used in this study is qualitative with a descriptive approach. With data collection techniques in the form of observation and documentation studies from research subjects, namely tutors / educators who have subjects in class XII (twelve) tested in the UPK Paket C program in 2021 at SKB SPNF Region I Padang City. The results of this study showed that the implementation of the evaluation of equality program (equality education exam) in Paket $C$ followed by students of class XII is known that students who carry out UPK use more online methods (google form).
\end{abstract}

Keywords: Learning Evaluation, Google Form, Paket $C$

\section{PENDAHULUAN}

Pendidikan di Indonesia terdiri dari 3 jalur Pendidikan, yaitu: pendidikan formal, non-formal dan informal. Banyak masyarakat yang berasumsi bahwa Pendidikan hanya terdapat dijalur formal dan kurang mengenal Pendidikan nonformal dan informal. Padahal 
Pendidikan nonformal sangat erat kaitannya dengan masyarakat.

Pendidikan nonformal adalah jalur pendidikan di luar pendidikan formal yang dapat dilaksanakan secara terstruktur dan berjenjang yang diselenggarakan bagi warga masyarakat yang memerlukan layanan pendidikan dan berfungsi sebagai pengganti, penambah, dan/atau pelengkap pendidikan formal dalam rangka mendukung pendidikan sepanjang hayat yang dapat berfungsi untuk mengembangkan potensi peserta didik dengan penekanan pada penguasaan pengetahuan dan keterampilan fungsional serta pengembangan sikap dan kepribadian profesional.

Pendidikan nonformal meliputi pendidikan kecakapan hidup, pendidikan anak usiadini, pendidikan kepemudaan, pendidikan pemberdayaan perempuan, pendidikan keaksaraan, pendidikan keterampilan dan pelatihan kerja, pendidikan kesetaraan, serta pendidikan lain yang ditujukan untuk mengembangkan kemampuan peserta didik.

Pendidikan kesetaraan merupakan jalur pendidikan nonformal dengan standar kompetensi lulusan yang sama dengan sekolah formal, tetapi konten, konteks, metodologi, dan pendekatan untuk mencapai standar kompetensi lulusan tersebut lebih memberikan konsep-konsep terapan, tematik, induktif, yang terkait dengan permasalahan lingkungan dan melatih kecakapan hidup berorientasi kerja atau berusaha sendiri. Kesempatan pendidikan harus diberikan secara merata, dipihak lain dituntut meningkatkan kualitas pendidikan (El Findri, 2001: 36-41). Pendidikan Kesetaraan ini mencakup program Paket
A setara SD/MI, Paket B setara SMP/IMTs, dan Paket C setara SMA/MA.

Pembelajaran adalah proses interaksi antara peserta didik dengan pendidik dan sumber belajarnya yang dilakukan pada suatu lingkungan belajar dan untuk Page|32 melihat tingkat keberhasilan pembelajaran diperlukan adanya evaluasi pembelajaran (Irwan, M., \& Fauziah, P. Y. 2017). Pada pendidikan kesetaraan, evaluasi pembelajaran dikenal dengan ujian penilaian kesetaraan (UPK). Berdasarkan juknis UPK tahun 2020/2021 moda pelaksanaan UPK dapat dilakukan dengan moda ujian berbasis luring atau daring. Hal ini dikarenakan adanya pandemi covid 19 yang menuntut setiap orang harus mematuhi protokol kesehatan. Di SPNF SKB Wilayah 1 Kota Padang sendiri memilih menggunakan google form sebagai alat evaluasi pembelajaran kesetaraan (UPK) secara daring.

\section{METODE}

Metode penelitian yang digunakan untuk menggolah informasi data yang dibutuhkan yaitu: metode penelitian deskriptif, kualitatif. Subjek penelitian terfokus pada tutor kesetaraan paket C dengan mata pelajaran Agama, Pendidikan Kewarganegaraan, Matematika, Bahasa Indonesia, Geografi, Sejarah, Sosiologi, Ekonomi dan Bahasa Inggris. data menggunakan teknik wawancara, observasi, dan dokumentasi. Teknik analisis yang digunakan reduksi data,display data,dan penarik kesimpulan. Lokasi penelitian dilakukan di SPNF SKB Wilayah 1 Kota Padang. Pelaksanaan penelitian dilakukan pada April 2021.

\section{HASIL DAN PEMBAHASAN}

Di SPNF SKB Wilayah 1 Kota Padang memiliki program kesetaraan didalamnya 
terdapat paket A setara dengan SD, paket $B$ setara dengan SMP dan paket $C$ setara dengan SMA. Pada paket $C$ terdapat kelas X (sepuluh), XI (sebelas), dan XII (dua belas). Program paket $C$ di SPNF SKB Wilayah 1 Kota Padang ini hanya menyediakan jurusan IPS.

Program kesetaraan Paket C merupakan program pembelajaran yang telah dilaksanakan oleh Direktorat Jenderal Pendidikan Non formal dan Informal di bawah binaan Direktorat Pendidikan Kesetaraan. Kebijakan mengenai pendidikan kesetaraan Paket C diatur dalam Keputusan Mendiknas Nomor 0132/U/2004. Sasaran program Paket $C$ adalah masyarakat lulusan Paket $\mathrm{B}$, siswa/siswi lulusan SMP/MTs, masyarakat yang telah mengikuti pendidikan informal yang disetarakan, serta masyarakat yang telah mengikuti pendidikan formal di SMA/MA namun mengalami putus sekolah. (kemendiknas 2004 dalam Rani Saidah, 2018)

Jumlah peserta didik paket C di SPNF SKB Wilayah 1 Kota Padang adalah sebanyak 128 orang yang terdiri dari kelas X sebanyak 63 orang, Kelas XI sebanyak 29 orang dan kelas XII sebanyak 36 orang.

Gambar: 1. Diagram Peserta Didik Paket C

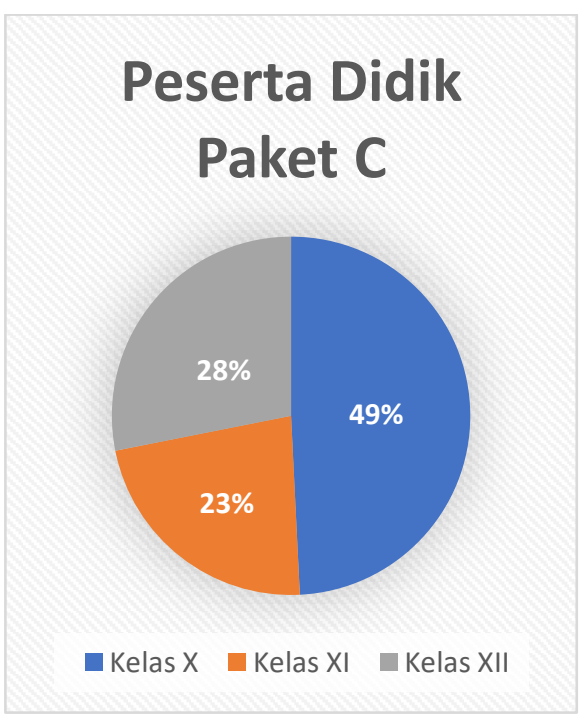

Sumber : Dokumentasi pribadi, 2021

Pembelajaran paket $C$ di SPNF SKB Wilayah 1 Kota Padang selama pandemi ini dilakukan secara daring dan luring. Pembelajaran secara luring dilakukan dengan tatap muka yaitu peserta didik datang langsung ke SPNF SKB Wilayah 1 Kota Padang dan ke lokasi belajar yang telah ditentukan oleh pihak pengelola yang menurut peserta didik lebih dekat dengan tempat tinggalnya dengan tetap menaati protokol kesehatan. Selain di SKB ada 3 lokasi pembelajaran yaitu di kelompok belajar Aur duri yang terletak di kecamatan Padang Timur, Anak Air berada di kecamatan koto Tangah dan Ulak karang berada di kecamatan Padang Utara.

Pembelajaran secara daring dilakukakan dengan memanfaatkan media sosial yaitu aplikasi whatsapp dan google form. Untuk mengetahui sejauh mana tingkat keberhasilan proses belajar mengajar diperlukan adanya evaluasi/ penilaian pada proses pembelajaran yang telah dilakukan.

$\begin{array}{ccr}\text { Menurut } & \text { Arikunto } & \text { (2010:2) } \\ \text { Evaluasi adalah } & \text { kegiatan } & \text { untuk } \\ \text { mengumpulkan } & \text { informasi } & \text { tentang }\end{array}$ bekerjanya sesuatu, yang selanjutnya informasi tersebut digunakan untuk menentukan alternative yang tepat dalam mengambil sebuah keputusan.

Senada dengan pernyataan Arikunto, dalam Permendikbud No. 23 Tahun 2016 tentang Standar Penilaian Pendidikan disebutkan bahwa penilaian adalah proses pengumpulan dan pengolahan informasi untuk mengukur pencapaian hasil belajar peserta didik. 
Jadi dapat disimpulkan bahwa evaluasi merupakan pengumpulan informasi yang dilakukan dengan melibatkan peserta didik untuk pengambilan keputusan selanjutnya dalam rangka perbaikan dan penguatan pembelajaran.

\section{Tujuan Evaluasi}

Evaluasi sendiri bertujuan untuk mengumpulkan, menganalisis, dan menyajikan informasi yang bermanfaat mengenai objek evaluasi, menilainya dengan membandingkannya dengan indikator dan hasilnya dipergunakan untuk mengambil keputusan mengenai objek evaluasi (Akbar \& Mohi,2018).

Sedangkan menurut Sudirman N, $\mathrm{dkk}$, bahwa tujuan penilaian dalam proses pembelajaran adalah:

1. Mengambil keputusan tentang hasil belajar

2. Memahami peserta didik

3. Memperbaiki dan mengembangkan program pembelajaran.

Fungsi utama evaluasi dalam hal ini adalah menyediakan informasi-informasi yang berguna bagi pihak decision maker untuk menentukan kebijakan yang akan diambil berdasarkan evaluasi yang telah dilakukan. dua dasar kegiatan dalam evaluasi, yaitu description dan judgement dan membedakan adanya tiga tahap dalam program pendidikan yaitu context, process dan outcomes (Schatt et al., 2016; Amir, 2020).

Jadi tujuan dari dilakukannya evaluasi/ penilaian pembelajaran adalah sebagai sumber informasi/ data yang bermanfaat untuk perbaikan dan pengembangan program pembelajaran selanjutnya.

Evaluasi pembelajaran kesetaraan dikenal dengan Ujian Pendidikan Kesetaraan (UPK). Hal ini juga tertuang Page|34 dalam Prosedur operasional standar Penyelenggaraan Ujian Pendidikan Kesetaraan Tingkat Satuan Pendidikan (POS UPK) tahun 2020/2021 menyatakan UPK adalah kegiatan pengukuran capaian kompetansi peserta didik yang dilakukan satuan Pendidikan dengan mengacu pada standar komptensi lulusan untuk memperoleh pengakuan atas prestasi belajar.

Adapun Persyaratan Peserta mengikuti UPK Paket $C$ adalah sebagai berikut:

1. Peserta didik telah atau pernah berada pada tahun terakhir pada Program Paket C;

2. Memiliki laporan lengkap penilaian hasil belajar setingkat SMA/MA/Sederajat, mulai kelas $\mathrm{X}$ semester 1 (satu) sampai dengan kelas XII semester 1 (satu) untuk peserta didik pada Program Paket C/Ulya.

3. Terdaftar di Tingkatan 6 Kelas XII pada Dapodik per tanggal 30 Desember 2020.

4. Peserta didik yang memiliki ijazah atau surat keterangan lain yang setara, atau berpenghargaan sama dengan ijazah dari Satuan Pendidikan yang setingkat lebih rendah. Penerbitan ijazah yang dimaksud sekurang kurangnya 3 (tiga) 
tahun sebelum mengikuti ujian Satuan Pendidikan.

\section{Mata Pelajaran, Jumlah Butir Soal, dan Alokasi Waktu}

Mata pelajaran yang diujikan dalam UPK ada 9 mata pelajaran yaitu Agama, Pendidikan Kewarganegaraan, Matematika, Bahasa Indonesia, Geografi, Sejarah, Sosiologi, Ekonomi dan Bahasa Inggris. Semua mata pelajaran memiliki jumlah soal yang sama kecauli mata pelajaran matematika yang jumlah soal pilihan ganda sebanyak zo soal dan uraian 10 soal.

Tabel: 1. Mata Pelajaran, Jumlah Butir Soal, dan Alokasi Waktu

\begin{tabular}{|c|c|c|c|c|}
\hline \multirow[t]{2}{*}{ No. } & \multirow[t]{2}{*}{ Mata Pelajaran } & \multicolumn{2}{|c|}{$\begin{array}{l}\text { Bentuk dan Jumlah } \\
\text { Butir Soal }\end{array}$} & \multirow[t]{2}{*}{ 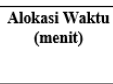 } \\
\hline & & PG & Uraian & \\
\hline 1 & Pendidikan Agama & 40 & 10 & 120 \\
\hline 2 & Pendidikan Kexwarganegaxaan & 40 & 10 & 120 \\
\hline 3 & Bahasa Indonesia & 40 & 10 & 120 \\
\hline 4 & Bahasa Imggris & 40 & 10 & 120 \\
\hline 5 & Matematika & 30 & 10 & 120 \\
\hline 6 & Geegrafi & 40 & 10 & 120 \\
\hline 7 & Sosiselegi & 40 & 10 & 120 \\
\hline 8 & Ekronomi & 40 & 10 & 120 \\
\hline 9 & Sejarah & 40 & 10 & 120 \\
\hline
\end{tabular}

Sumber: POS UPK 2021

\section{Pelaksanaan UPK}

Ujian Pendidikan Kesetaraan (UPK) Paket $C$ dilakukan sesuai dengan jadwal yang telah ditentukan dan dilakukan secara daring serta luring. Ujian secara Luring dilaksanakan di SPNF SKB Wilayah 1 Kota Padang, yaitu peserta didik datang langsung ke SPNF SKB Wilayah 1 Kota Padang dan melaksanakan UPK di ruang yang telah disediakan oleh pihak pengelola dengan membawa perlengkapan yang dibutuhkan utuk mengerjakan ujian tersebut.

Ujian yang dilakukan secara daring yaitu menggunakan google form. Google Form atau yang disebut google formulir adalah alat yang berguna untuk membantu dalam merencanakan acara, mengirim survei atau mengumpulkan informasi yang mudah dengan cara yang efisien. Form juga dapat dihubungkan ke spreadsheet. Jika speadsheet terkait dengan bentuk, tanggapan otomatis akan Page|35 dikirimkan ke spreadsheet. Jika tidak pengguna dapat melihat di ringkasan tanggapan halaman dapat diakses dari menu Tanggapan. Salah satu alasan dari banyak pengguna yang mungkin tidak menyadari Google Form adalah bahwa google form ditemukan bukan sebagai aplikasi terpisah, melainkan sebagai bagian dari Google Drive. Dengan demikian untuk membuat formulir baru, kita harus terlebih dahulu login ke Gmail atau Google Apps. Dengan spreadsheet memungkinkan untuk menunjukkan berbagai pertanyaan, termasuk dimana pengguna anda merespon dengan jawaban teks sederhana atau respon teks lebih lanjut, kita dapat meminta pertanyaan pilihan ganda, daftar pertanyaan, pertanyaan skala, dan banyak lagi. Ketika berbagi formulir kita dengan orang lain kita dapat mengatur mereka untuk tampil dengan tema yang mengesankan dengan akses yang mudah. Google Form adalah bagian dari Google Drive, maka kita harus memiliki akun gmail terlebih dahulu. Silahkan registrasi terlebih dahulu jika belum memiliki akun Google (Maxima Ari Saktiono, 2019)

Cara penggunaan google form sebagai evaluasi pembelajaran ujian pendidikan kesetaraan (upk) paket c secara daring ada 2cara. Cara pertama adalah sebagai berikut;

1. Bagi tutor yang belum memiliki akun google maka tutor terlebih dahulu membuat akun google

2. Setelah memiliki akun google tutor membuka Situs Google Form di www.google.com/forms/about/ 
3. Selanjutnya, akan muncul pilihan untuk membuka google form dalam halaman ini, lalu tutor mengklik tautan Buka Google Formulir.

4. Setelah itu akan muncul beberapa template yang dapat dipilih oleh tutor sesuai keinginan dan kebutuhan.

5. Setelah memilih template akan muncul halaman form kosong yang siap untuk diisi oleh tutor dengan pertanyaan identitas peserta didik dan soal ujian yang akan diujikan sesuai dengan mata pelajaran yang diampuh oleh tutor.

6. Selanjutnya, setelah tutor mengisi google form, tutor menekan tautan kirim. Maka akan muncul link tautan dari google form

7. Lalu tutor menyalin link yang ada ditautan dan mengirimkan link tersebut ke Wathsapp grup Paket C kelas XII

8. Langkah terakhir peserta didik dapat mengikuti ujian UPK dengan mengklik tautan link yang telah dikirim tutor ke grup dan mengisi identitas diri serta menjawab soal-soal.

Cara kedua melalui google drive, adalah sebagai berikut:

1. Masuk ke akun gmail masingmasing tutor

2. Klik menu aplikasi Google. Menu ini berupa kotak sembilan titik di pojok kanan atas layar, di sebelah kiri gambar akun Gmail Anda

3. Klik pilihan "Drive". Langkah ini akan membuka akun Google Drive Anda. Bergantung pada aplikasi yang sering digunakan, di sini Anda mungkin akan melihat opsi
"Formulir". Jika ya, klik untuk membuka Google Formulir.

4. Klik tombol "Baru". Tombol ini ada di sisi kiri atas halaman Drive Anda, tepat di atas opsi "Drive Saya".

5. Tempatkan kursor pada "Lainnya", lalu klik "Google Formulir". Langkah ini akan membuka Google Formulir baru tanpa judul!

6. Jika Anda perlu membuka formulir baru dari beranda Google Formulir, klik tombol "+" di sisi kiri template formulir.

\section{Pelaksanaan ujian dilaksanakan}

Ujian UPK paket $C$ kelas XII di SPNF SKB Wilayah 1 Kota Padang dilaksanakan selama 4. Peserta didik memulai ujian pertamanya pada hari Senin, 29 Maret 2021 yaitu mata pelajaran Agama dan Matematika yang dimulai pukul 07.30 - 09.30 WIB dan diperbolehkan istirahat selama 30 menit sebelum melanjutkan ujian kedua yaitu pukul 10.00-12.00 wib.

Sedangkan hari ke 2, 3 dan 4 peserta didik melaksanakan ujian dengan 3 mata pelajaran susai dengan jadwal yang ditetapkan pada tabel berikut:

Tabel: 2. Jadwal pelaksanaan UPK

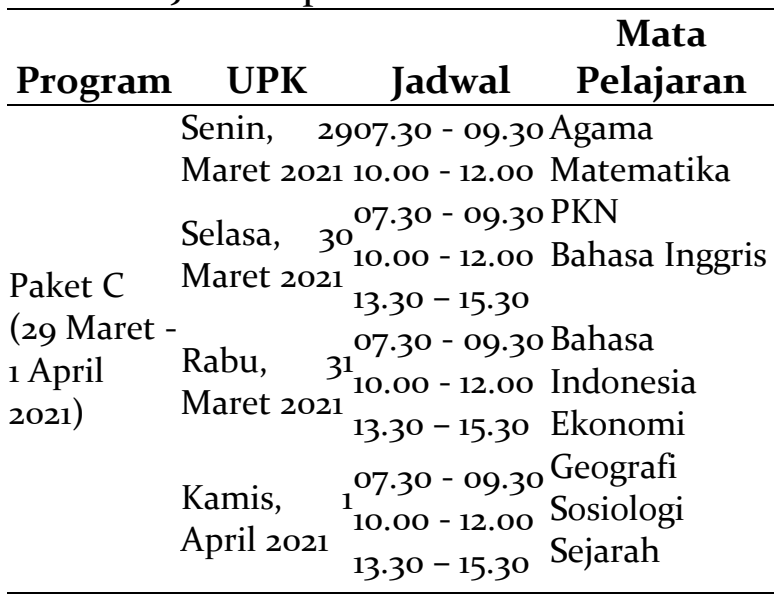

Sumber: POS UPK 2021 
Bagi peserta didik yang tidak dapat mengikuti ujian UPK secara daring maupun luring sesuai dengan jadwal yang telah dituntukan. Maka peserta didik dapat melaksanakan ujian susulan. Ujian susulan UPK dilaksanakan maksimal 7 (tujuh) hari setelah pelaksanaan ujian. Jadwal sesuai dengan tabel berikut:

Tabel: 3. Jadwal pelaksanaan susulan UPK

\begin{tabular}{|c|c|c|c|}
\hline Program & UPK & Jadwal & $\begin{array}{c}\text { Mata } \\
\text { Pelajaran }\end{array}$ \\
\hline \multirow{16}{*}{$\begin{array}{l}\text { Paket C } \\
\text { (5-8 April } \\
\text { 2021) }\end{array}$} & \multirow{5}{*}{$\begin{array}{l}\text { Senin, } \\
\text { April } 2021\end{array}$} & $07 \cdot 30$ & -Agama \\
\hline & & $509 \cdot 30$ & Matematika \\
\hline & & 10.00 & - \\
\hline & & 12.00 & \\
\hline & & 07.30 & -PKN \\
\hline & \multirow{3}{*}{$\begin{array}{l}\text { Selasa, } \\
\text { April } 2021\end{array}$} & $609 \cdot 30$ & Bahasa \\
\hline & & 10.00 & -Inggris \\
\hline & & 12.00 & \\
\hline & \multirow{4}{*}{$\begin{array}{l}\text { Rabu, } \\
\text { April } 2021\end{array}$} & $07 \cdot 30$ & -Bahasa \\
\hline & & $709 \cdot 30$ & Indonesia \\
\hline & & 10.00 & -Ekonomi \\
\hline & & 12.00 & \multirow{5}{*}{$\begin{array}{l}\text {-Geografi } \\
\text { Sosiologi } \\
\text {-Sejarah } \\
\text { o }\end{array}$} \\
\hline & \multirow{4}{*}{$\begin{array}{l}\text { Kamis, } \\
\text { April } 2021\end{array}$} & $07 \cdot 30$ & \\
\hline & & $8^{09 \cdot 30}$ & \\
\hline & & 10.00 & \\
\hline & & $\begin{array}{l}12.00 \\
13.30-15.30\end{array}$ & \\
\hline
\end{tabular}

Sumber: POS UPK 2021

\section{Proses pemeriksaan dan pengolahan hasil UPK}

A. Soal Bentuk Pilihan Ganda

Soal UPK berbentuk pilihan ganda dapat diperiksa secara manual oleh tutor masing-masing mata pelajaran, menggunakan alat pemindai dan atau menggunakan hasil otomatis aplikasi.

B. Soal Bentuk Uraian

1. Soal bentuk uraian diperiksa secara manual oleh tutor masingmasing mata pelajaran sesuai mata pelajarannya, mengacu pada pedoman penskoran yang sudah ditentukan
2. Nilai akhir soal uraian adalah rerata nilai dari hasil pemeriksaan.

C. Pengolahan Hasil UPK

1. Nilai UPK $m$ erupakan gabungan nilai soal pilihan ganda dan nilai soal uraian, dengan rentang nilai o Page | 37 - 100.

2. SPNF SKB Wilayah I Kota Padang berhak menentukan pembobotan nilai pilihan ganda dan uraian dengan perbandingan yang proporsional.

\section{Hasil Pelaksanaan UPK}

Gambar: 2. Hasil UPK mata pelajaran ekonomi

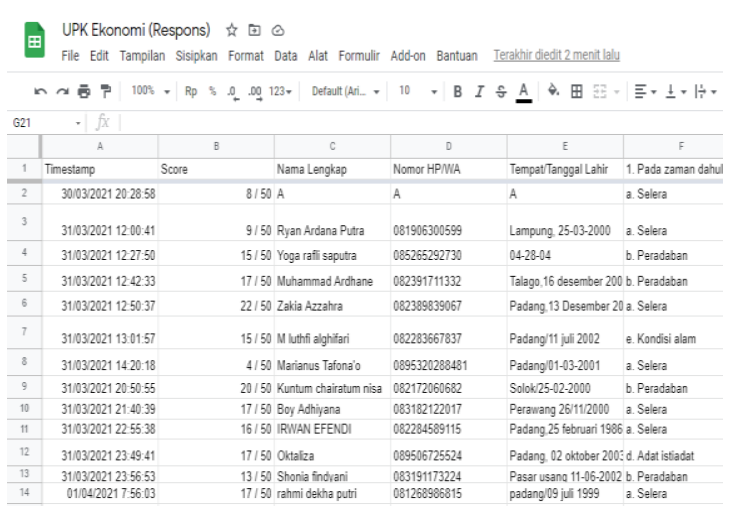

Sumber : Dokumentasi tutor, 2021

Peserta didik paket $C$ kelas XII di SPNF SKB Wilayah 1 Kota Padang yang mengikuti ujian secara daring (melalui google form) ada sebanyak 13 orang (39\%). Sedangkan yang mengikuti ujian luring atau datang langsung ke SPNF SKB Wilayah 1 Kota Padang ada sebanyak 8 orang $(21 \%)$. Sedangkan 9 orang (24\%) lainnya mengikuti ujian susulan yaitu peserta didik yang tidak dapat datang ke SPNF SKB Wilayah 1 Kota Padang dan juga tidak dapat melakukan ujian secara daring (melalui google form) sesuai jadwal yang telah ditentukan. Maka mereka melakukan ujian di rumah masing-masing dengan diawasi oleh tutor. Dan 6 orang peserta didik yang 
tidak mengikuti UPK dinyatakan tidak lulus dalam program kesetaraan paket $C$.

\section{KESIMPULAN}

Hasil penelitian yang telah dilakukan menunjukkan, dari 36 peserta didik paket $C$ kelas XII yang terdaftar mengikuti ujian Pendidikan kesetaraan. Terdapat sebanyak 8 orang $(21 \%)$ mengikuti ujian secara luring (datang ke SPNF SKB Wilayah 1 Kota Padang) dan 13 orang (39\%) mengikuti ujian secara daring (melalui google form) dan yang melakukan ujian susulan ada sebanyak 9 orang $(24 \%)$ sedangkan yang tidak menghikuti ujian ada sebanyak 6 orang $(16 \%)$.

Maka dapat disimpulkan bahwa peserta didik yang mengikuti ujian Pendidikan kesetaraan lebih banyak yang memilih ujjian secara daring (melalui google form) yaitu sebanyak 13 orang atau sebesar $39 \%$.

\section{DAFTAR PUSTAKA}

Akbar, M. F., \& Mohi, W. K. (2018). Studi Evaluasi Kebijakan (Evaluasi Beberapa Kebijakan di Indonesia). Gorontalo: Ideas Publishing

Amir, A. (2020). Public Policy Implementation: Study on Educational Budgeting of Palopo. Journal La Sociale, 1(1), 5-11.

Arikunto, S. 2010. Prosedur Penelitian Suatu pendekatan praktik. Jakarta: PT Rineka Cipta

Sudirman dkk, Ilmu Pendidikan, Cet. I; Bandung: Sinar Baru 1991

Kemendikbud. 2016. Permendikbud No. 23 tentang Standar Penilaian Pendidikan, Jakarta: Kemendikbud
Kemendikbud. 2021. Prosedur operasional standar Penyelenggaraan Ujian Pendidikan Kesetaraan Tingkat Satuan Pendidikan (POS UPK). Jakarta: Kemendikbud

Maxima Ari Saktiono. 2019. Jurnal Aplikasi Pelayaran dan Kepelabuhanan, Volume 9: Penerapan Google Form Untuk Evaluasi Kehadiran Perkuliahan Taruna-Taruni Teknika PDP UHT.

Wulandari, pitri. Dkk. 2019. Prosiding Seminar Nasional Pendidikan FKIP: Google Form Sebagai Alternatif Evaluasi Pembelajaran Di Sman 2 Kota Tangerang.

Nofitasari, Eva L. 2020. Jurnal Pendidikan dan Pembelajaran Dasar: Pelaksanaan Evaluasi Pembelajaran Berbasis Google Form Selama Masa Pandemi Pada Peserta Didik SD/MI

Irwan, M., \& Fauziah, P. Y. (2017). Evaluasi program pelatihan keterampilan mengolah limbah kertas semen pada PKBM Cahaya Kota Binjai. JPPM (Jurnal Pendidikan dan Pemberdayaan Masyarakat), 4(2), 121-132.

Thoyyibatul Amalia. 2019. Prosiding konferensi Nasional Bahasa Arab V: Penggunaan Media Google Form Dalam Evaluasi Pembelajaran Bahasa Arab Maharah Kitabah

Saidah, Rani. 2018. Jurnal Pendidikan Luar Sekolah vol. 12. Evaluasi Pembelajaran Kesetaraan Paket C Dalam Meningkatkan Kualitas Lulusan https://id.wikihow.com/MembuatFormulir-Menggunakan-Google-Drive diakses pada tanggal 11 Mei 2021 pada pukul 11.30 WIB. 
Journal of Millennial Community, 3 (1), March 2021

Lilis Swarni Nainggolan, Arif Nur Rohman

Nurhayati, Lia. Srihandayani Suprapto.

2020. Publik (Jurnal Ilmu

Administrasi) Vol 9: Publik (Jurnal

Ilmu Administrasi) Vol 9

\section{PROFIL SINGKAT}

Penulis pertama Lilis Swarni Nainggolan, lahir di Serdang Bedagai, Sumatera utara, 15 Agustus 1992. Menyelesaikan pendidikan Sarjana Pendidikan Luar Sekolah di Fakultas pendidikan, Universitas Negeri Medan pada tahun 2014. Pekerjaan saat ini sebagai Pamong Belajar di SPNF SKB Wilayah 1 Kota Padang.

Penulis kedua Arif Nur Rohman, lahir di Sleman, D. I. Yogyakarta 5 Agustus 1995. Menyelesaikan pendidikan Sarjana Pendidikan Luar Sekolah di Fakultas Ilmu Pendidikan Universitas Negeri Yogyakarta pada tahun 2018. Pekerjaan saat ini sebagai Pamong Belajar di SPNF SKB Wilayah 1 Kota Padang. 